\title{
Ionospheric research in Germany prior to Karl Rawer
}

\author{
K. Schlegel \\ Copernicus Gesellschaft e.V., Bahnhofsallee 1e, 37081 Göttingen, Germany \\ Correspondence to: K. Schlegel (kristian.schlegel@copernicus.org)
}

Received: 23 November 2013 - Accepted: 30 November 2013 - Published: 10 November 2014

\begin{abstract}
This brief historical review summarizes the work and achievements of German researchers on ionospheric problems before Karl Rawer started his scientific career in 1937.
\end{abstract}

\section{Introduction - basic milestones towards ionospheric research}

A necessary prerequisite of any ionospheric research was the unification of electricity and magnetism by James Clerk Maxwell (1873). Since electromagnetic waves played a fundamental role in this research their discovery by Heinrich Hertz in 1887 was another basic milestone (Dittmar-Ilgen, 2007). Similarly important was the work by Karl Ferdinand Braun who fundamentally improved earlier radio wave transmitters and introduced the cathode ray tube (Zenneck, 1955). The first practical encounter of electromagnetic waves with the ionosphere constituted 1901 the trans-atlantic radio signal transmissions by Guglielmo Marconi (Beckmann, 1974) which earned him the Nobel Price 1909 (together with the just mentioned K. F. Braun). In order to explain Marconi's results Arthur Edvin Kennelly and Oliver Heaviside postulated 1902 a conducting layer in the upper atmosphere (Beckmann, 1974). For completeness it should be mentioned here that already C. F. Gauss speculated in 1838 about such a layer inspired by his geomagnetic field investigations. It took more than two decades before the existence of this layer was experimentally proven by Edward Victor Appleton (Appleton and Barnett, 1925). Only two years later, 1926, Robert WatsonWatt coined the term ionosphere (Beckmann, 1974).

In the following we will sketch the early ionospheric work in Germany by focussing on the scientists who performed it.

\section{Jonathan Zenneck}

The most important and influential ionospheric pioneer in Germany was certainly Jonathan Zenneck (1871-1959), Karl Rawer called him the "father of the German ionospheric physics". Zenneck first studied theology and natural sciences at the University of Tübingen from 1889 to 1894 and received a $\mathrm{PhD}$ in zoology. He almost decided to become a zoologist, but discussions with the above mentioned K. F. Braun aroused his interest in HF techniques and he became an assistant of Braun at the University of Straßburg from 1895-1905. During this time he performed his first experiments in wireless telegraphy in order to establish a maritime radio service at the shore of the North Sea in Cuxhaven. In 1905 he published a textbook on wireless telegraphy, the first of this kind in Germany.

In the same year he received a call as "außerordentlicher" Professor to the University of Danzig. His time there was short, already in 1906 he became Professor at the Technical University of Braunschweig. From 1907 to 1911 he went to industry for research at the Badische Anilin- und Sodafabrik. In 1911 he returned to Danzig as a full Professor, and in 1913 he received a call to the Technical University of München on the renowned Chair of Experimental Physics. There he stayed until his retirement in 1939. Besides his scientific work and teaching he was Chair of the Board of the Deutsches Museum in München from 1933-1953. Zenneck received many scientific awards and honours, among them "Großes Verdienstkreuz der Bundesrepublik Deutschland". He also became Vice President of the Union Radio Scièntifique International (URSI) after Germany joined this organisation in 1938.

We will not deal here in detail with Zenneck's extensive work on radio wave propagation in the years from 1902 to 1930. His ionospheric investigations started in 1929 when he performed first experiments with a broadcasting transmitter 


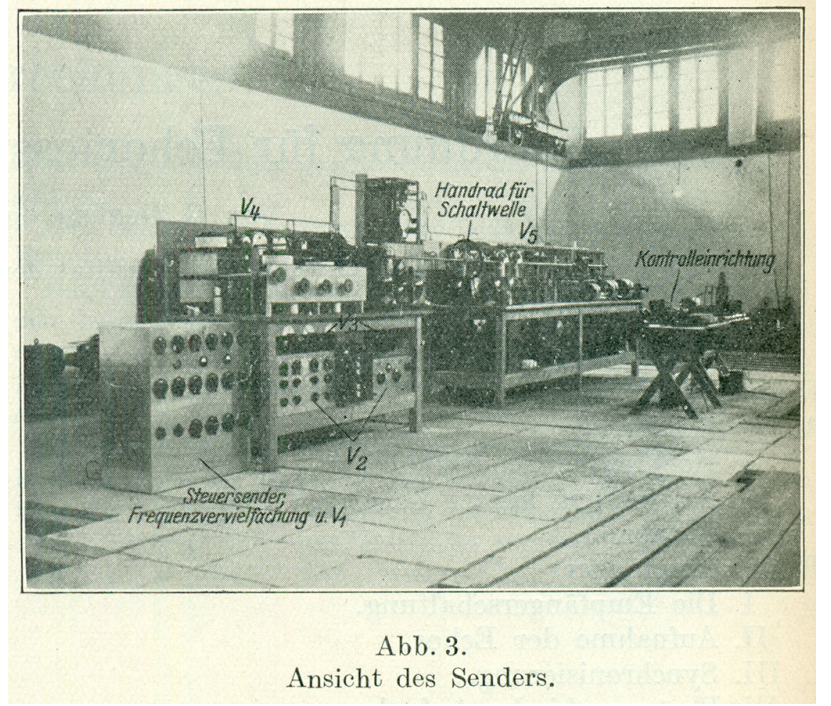

Figure 1a. The transmitter of the research station Herzogenstand (Goubau and Zenneck, 1932).

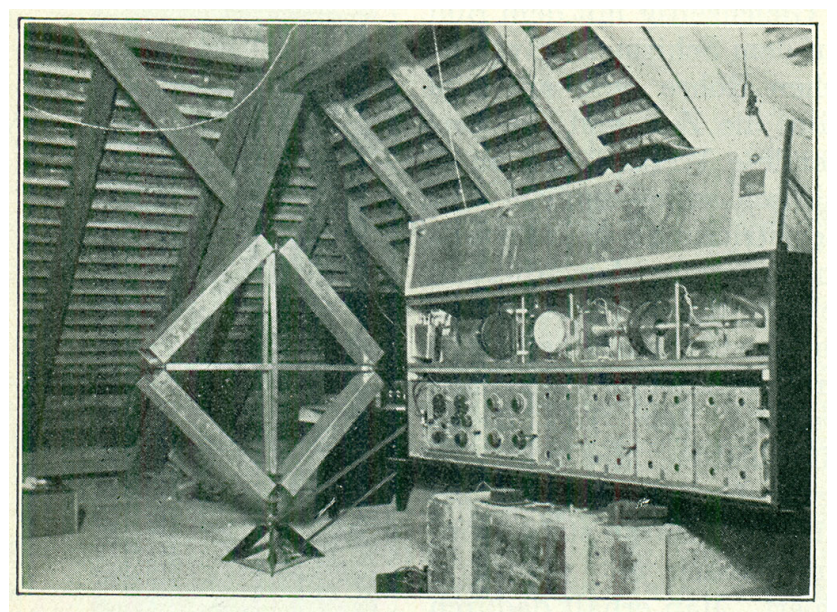

Abb. 9.

Ansicht des Empfängers.

Figure 1b. The receiver of the research station Herzogenstand (Goubau and Zenneck, 1932).

in München, at night after the end of the regular programme. Only one year later he and his collaborators (G. Goubau, and others, see below) established their own research station on top of the Herzogenstand, a mountain near München. They built a first type of ionosonde capable of pulse sounding as well as continuous transmitting, and used for the first time Braun's cathode ray tube for diagnosis (Fig. 1a and b). Among their research subjects were

- measurements of echo height and its daily and seasonal variations,

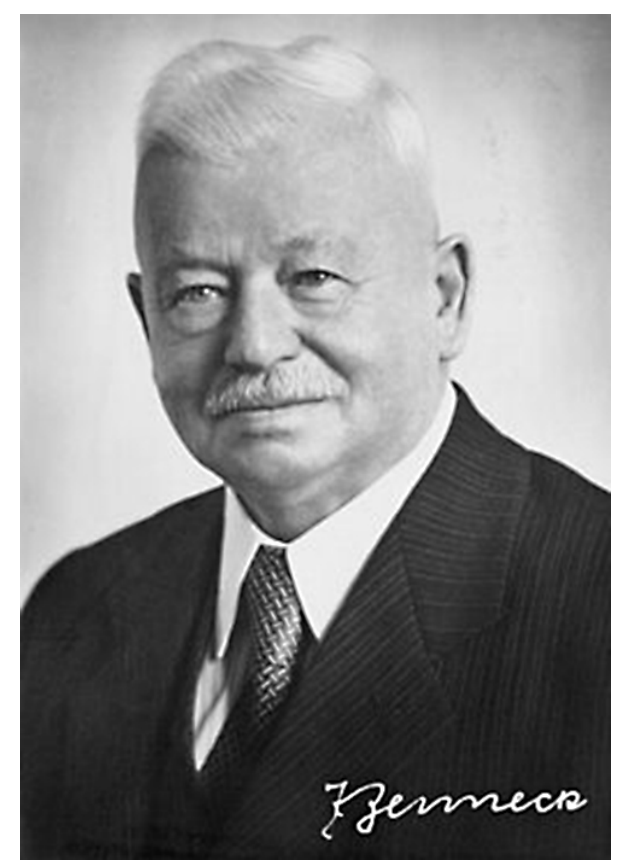

Figure 2. Jonathan Zenneck (Public Domain, Wikipedia).

- measurements of critical frequency (electron density) and its daily and seasonal variations,

- investigations of irregular variations of ionospheric parameters, e.g. solar activity dependence (together with the magnetic observatories at Göttingen and Potsdam),

- the behaviour of ionospheric layers during a solar eclipse,

- the influence of precipitating particles on ionospheric parameters (in collaboration with Carl Störmer, Oslo and Leif Harang, Tromsö),

- theoretical work: magnetic polarization of radio waves, dispersion of radio waves in a plasma,

- improvements of sounding techniques,

- radio wave propagation forecast.

A detailed description of the life and work of Zenneck (Fig. 2), including a complete list of his publications is given in Schmucker (1999).

\section{Zenneck's important PhD students and collaborators}

One of Zenneck's oldest PhD student and collaborator was Johannes Plendl (1900-1992), Fig. 3a. After finishing his $\mathrm{PhD}$ in 1925 he developed devices for long-range short-wave communication with the German company Telefunken, and 


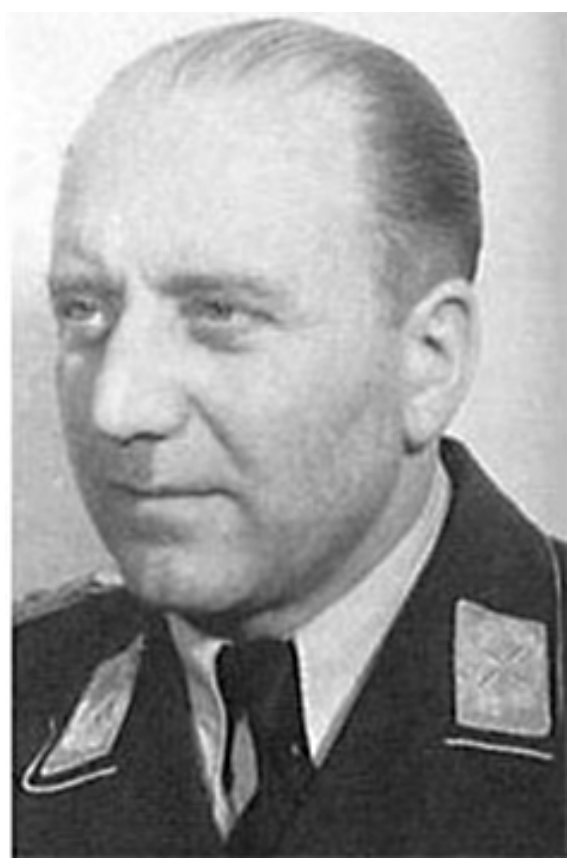

Figure 3a. Johannes Plendl (http://www.ae5x.com/blog/2013/06/ 06/hier-ist-london-and-the-coining-of-the-term-ionosphere/).

from 1927 on at the "Deutsche Versuchsanstalt für Luftfahrt". In 1934 he became Director of the section F ("Flugfunk") of the military (German air force) "Erprobungsstelle" (test facility) in Rechlin (about $200 \mathrm{~km}$ north of Berlin), developing radio beam guiding systems (System "Knickebein"). He also established regular radio wave propagation forecasts in "Gruppe I" of this section, and installed W. Dieminger (see below) as head of this group. In 1947 he came to the US with the "Operation Paperclip", working at the Air Force Cambridge Research Laboratory. After his retirement in 1970 he returned to Germany (for more details, see Seiler, 2007).

Georg Goubau (1906-1980), Fig. 3b, was Zennecks's main collaborator in establishing and operating the research station Herzogenstand. In 1939 he became full Professor at the University of Jena and was engaged in the development of microwave techniques. More about Goubau can be found in his obituary (Schwering, 1981).

A student of Zenneck, very influential for ionospheric research, was Walter Dieminger (1907-2000), Fig. 3c. After his $\mathrm{PhD}$ in 1935 he became the head of the radio wave propagation unit of the "Erprobungsstelle Rechlin" (Group I of Section F). His group was very successful in providing propagation forecasts for the Germany military, which during WW2, was spread over whole Europe. His successful work was acknowledged by the American, British, and French forces, and after the war all three tried to capture his group. The British were successful and under the command of (the science officer) Roy Pigott (and with support from Apple-

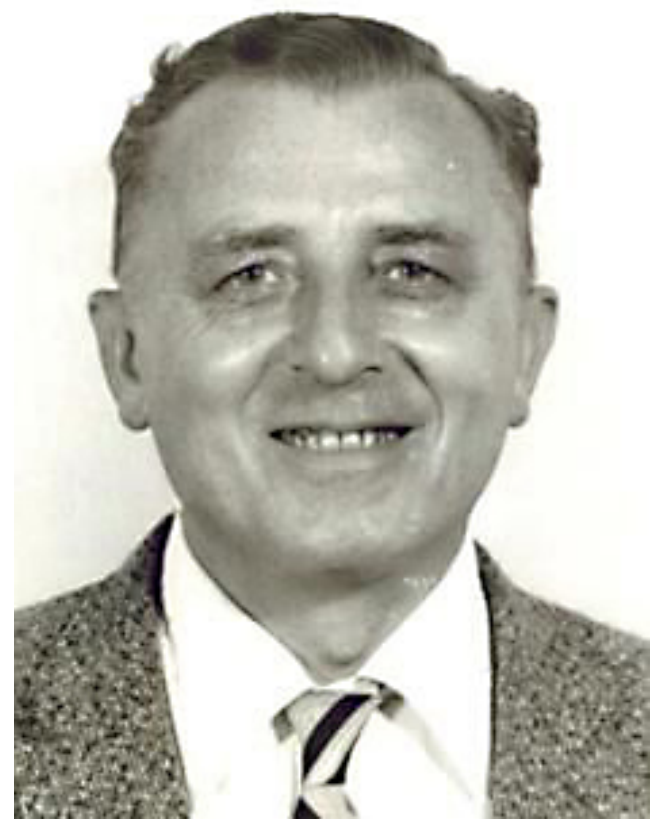

Figure 3b. Georg Goubau (Professoren der Univ. Jena, http://www. physik.uni-jena.de/-p-264.html?rewrite_engine=id).

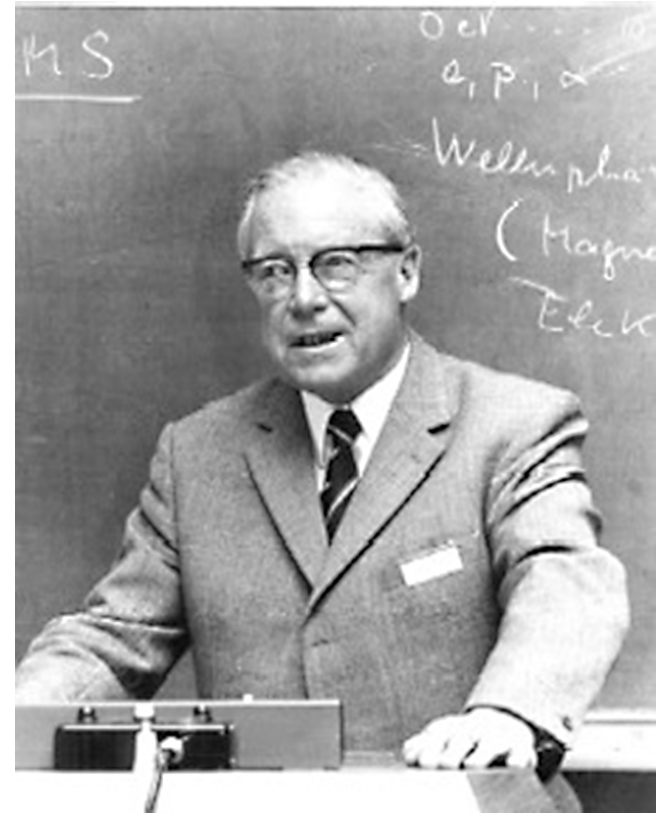

Figure 3c. Walter Dieminger (Hartmann, 2001).

ton) Dieminger's group was brought to the British sector, to Lindau/Harz (Gerwin, 1981). As a consequence of their important scientific achievements Dieminger's group became a member of the Kaiser-Wilhelm-Gesellschaft (KWG) in 1946. After the KWG was dissolved 1951 and re-established as Max-Planck-Gesellschaft, Dieminger became the Director of the Max-Planck-Institut für Aeronomie in Lindau and 


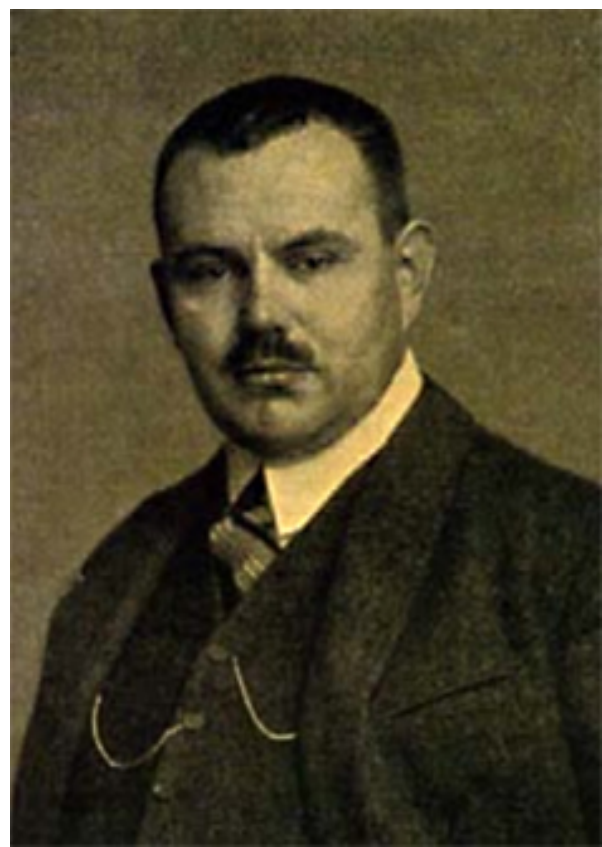

Figure 3d. Hans Rukop, Die Telefunkenröhre und Ihre Geschichte, in: Festschrift 25 Jahre Telefunken, 114, 1928 (www.cdvandt.org/ 25-Jahre-Telefunken-part-2.pdf).

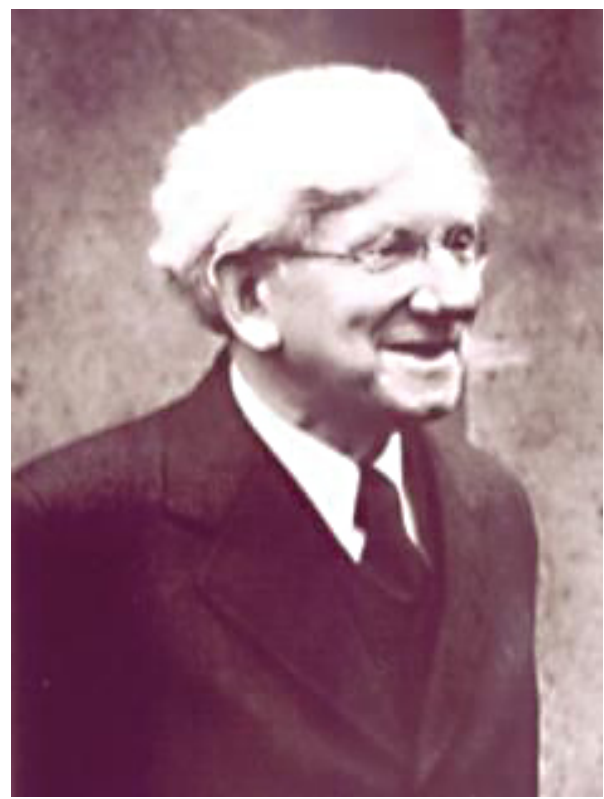

Figure 4a. Karl Försterling (Professoren der Univ. Jena, http:// www.physik.uni-jena.de/-p-220.html?rewrite_engine=id).

remained in this position until his retirement. Dieminger himself introduced many young scientist (among them the author) to the field of ionospheric physics and his institute became well known all over the world. Dieminger was from 1966-1969 Vice President and from 1969-1972 President

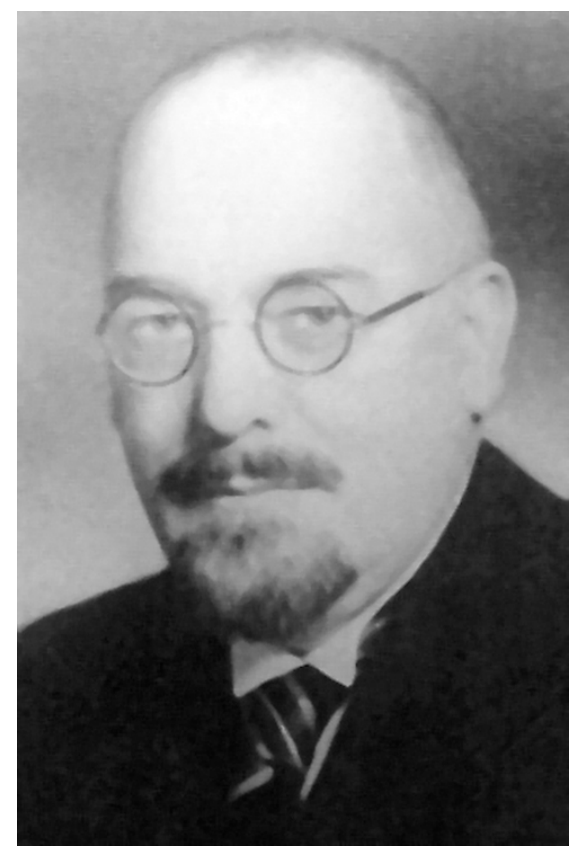

Figure 4b. Karl Willy Wagner (TU Berlin, http: //www.nue.tu-berlin.de/menue/home/geschichte/historische_ persoenlichkeiten/kw_wagner/).

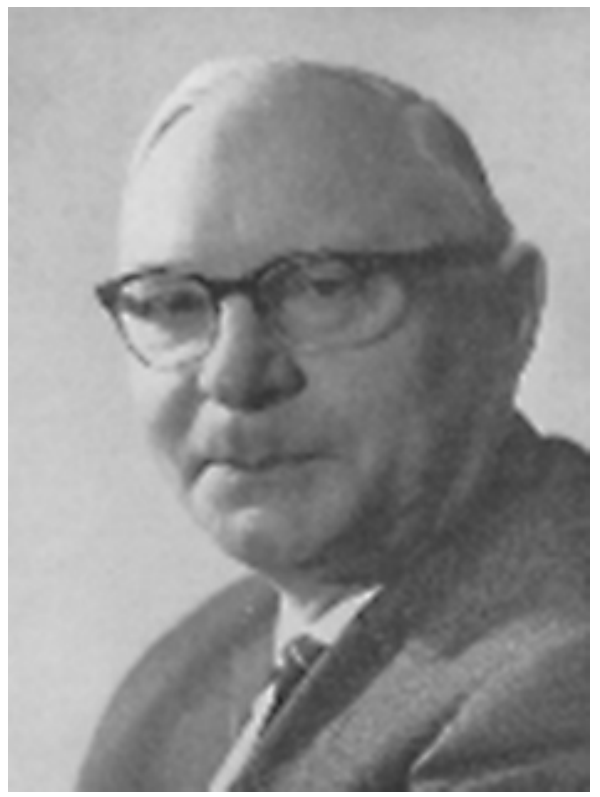

Figure 4c. Julius Bartels (GWDG Göttingen, http://wwwuser. gwdg.de/ rhennin/bartels.html).

of URSI. For more details about Dieminger, see Hartmann (2001).

Rudolf Eyfrig (1911-2011) was, after his $\mathrm{PhD}$ in 1937, an important collaborator of Zenneck at the research station Herzogenstand. After the war he was Director of the 


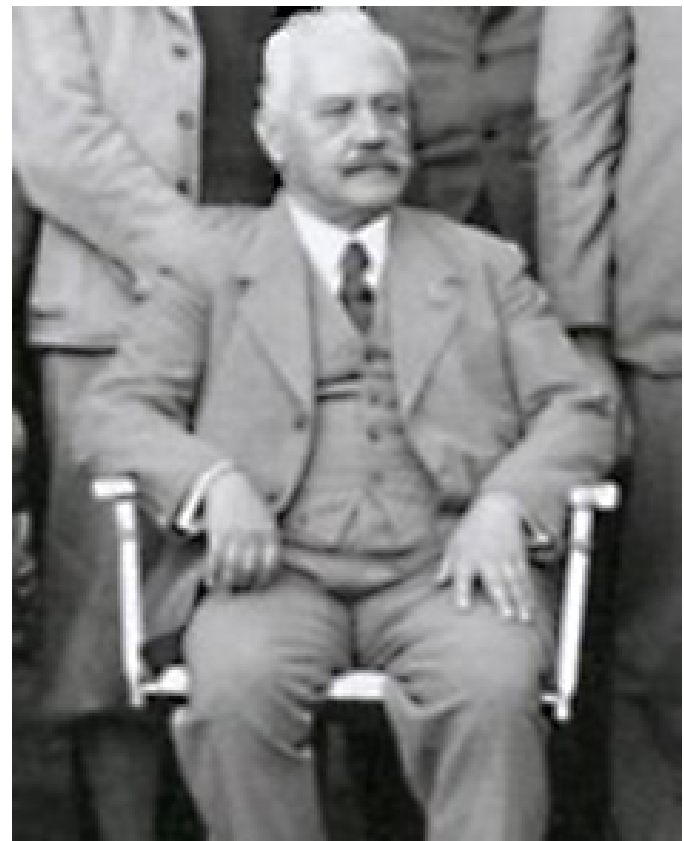

Figure 4d. Arnold Sommerfeld (GNU Free Documentation License, Wikipedia).

Ionospheric Research Office of the Deutsche Bundespost. Most of Eyfrig's publications are listed in Beckmann (1974).

Hans Rukop (1883-1958), Fig. 3d, was not a PhD student of Zenneck, but of Richard Mie at the University of Greifswald. However he joined Zenneck during his time in Danzig and followed him to München in 1913 were both continued their successful scientific collaboration. His speciality was the development of vacuum tubes. Later Rukop became the Director of vacuum tube production at the Telefunken company (Blumentritt, 1955).

\section{Other important German ionospheric scientists}

Karl Försterling (1885-1960), Fig. 4a, received his $\mathrm{PhD}$ at the University of Göttingen in 1909, since 1938 he was professor for theoretical physics at the University of Köln (Scheffczyk, 2011). He performed fundamental theoretical work on radio wave propagation mainly with Hans Lassen (1897-1947). Lassen published in 1926 his famous radio wave dispersion formula, known as Appleton-LassenEquation.

Hans Ernst Mögel (1900-1944) worked with Hans Barkhausen at the Technical University of Dresden and received his $\mathrm{PhD}$ there in 1927. After that he became the leader of the trans-continental wireless station Beelitz (south of Berlin) operated by Transradio a branch of Telefunken (Fritz Traxler, personal communication, 2011). In 1930 he published his famous paper about the absorption of radio waves in the $\mathrm{D}$ region during solar flares (sudden ionospheric disturbance, SID, Mögel, 1930). Although the American scientist John Howard Dellinger published similar results five years later in 1935 the corresponding phenomenon is called Mögel-Dellinger Effect.

Karl Willy Wagner (1883-1953), Fig. 4b, received his $\mathrm{PhD}$ at the University of Göttingen in 1910 and was appointed Professor at the Technical University of Berlin in 1927. In the year 1930 he founded the Heinrich-HertzInstitut in Berlin where important work on radio wave propagation and ionospheric investigations were performed in the following decades. Wagner was a participant in the International Polar Year 1932/33, and conducted important ionospheric investigations in Tromsö together with Harang and Appleton. More details about his work and life together with a complete list of his publications can be found in Frühauf (1956). His colleague Willy Stoffregen (1909-1987) a talented engineer and scientist developed the equipment for the measurements during the International Polar Year (Stoffregen, 1984)

Very little known in the scientific community is Bernhard Düll (1908-1983). He received his PhD at the University of Rostock 1932. He was a pioneer in establishing solarterrestrial relations, and published papers of solar influence not only on the ionosphere but also on weather and human mortality (see Halberg et al., 2013).

Very important for ionospheric research was Julius Bartels (1899-1964), Fig. 4c, although he mostly worked on geomagnetism. He received his $\mathrm{PhD}$ in 1923 at the University of Göttingen and then worked together with the famous geomagnetician Adolf Schmidt at the observatory of Potsdam. 1928 he became Professor at Eberswalde and in 1936 Director of the Potsdam Magnetic Observatory. From 1946 until his retirement he was Professor for Geophysics at the University of Göttingen, and 1955-1964 simultaneously Director of the Max-Planck-Institut für Stratosphärenphysik (section of the Max-Planck-Institut für Aeronomie, see previous section). His two-volume book "Geomagnetism" (together with Sidney Chapman) was and still is a widely referenced standard textbook (Chapman and Bartels, 1940). More details can be found in his biography written by Kertz (1965).

Last not least Arnold Sommerfeld (1868-1951), Fig. 4d, should be mentioned here, in particular since Karl Rawer was very impressed by his knowledge, his teaching and his seminars. Sommerfeld studied in Königsberg where he received his $\mathrm{PhD}$ in 1891. After professorships at the University of Göttingen and the Technical University of Aachen, he became 1906 professor for theoretical physics at the University of München where he stayed until his retirement. He did not publish specific papers on ionospheric physics, but on radio wave propagation. He also was a friend and respected colleague of Zenneck and took part in many discussions on ionospheric problems. 


\section{Concluding remark}

The previous sections show that Karl Rawer could already count on substantial ionospheric work and results from German scientists, as well as from the international literature (e.g., Kenrick and Pickard, 1930) when he started his PhD thesis in 1937 at Zenneck's institute. A review of the early history of ionospheric research from an international point of view has been provided by Green (1946).

Edited by: M. Förster

Reviewed by: G. K. Hartmann and P. Wilkinson

\section{References}

Appleton, E. V. and Barnett, M. A. F.: On some direct evidence for downward atmospheric reflection of electric rays, P. R. Soc. Lond. A, 109, 612-641, 1925.

Beckmann, B.: Die Entdeckungsgeschichte der Radiowellenausbreitung in den ersten fünfzig Jahren mit besonderer Berücksichtigung der deutschen Arbeiten, in: Zur Geschichte der Geophysik, Hrsg.: Birett, H., Helbig, K., Kertz, W., and Schmucker, U., Springer-Verlag Berlin - Heidelberg - New York, 1974, (http: //www.dgg-online.de/geschichte/birett/BAND1S.HTM).

Blumentritt, O.: Rukop, Hans, in: Neue Deutsche Biographie, 22, 243, Duncker \& Humblot, Berlin, 2005.

Chapman, S. and Bartels, J.: Geomagnetism, Oxford, Clarendon Press, 1940.

Dittmar-Ilgen, H.: 120 Jahre Radiowellen, Naturw. Rundschau, 60, 303-305, 2007.

Eckert, M.: Arnold Sommerfeld, Atomphysiker und Kulturbote, 1868-1951. Eine Biografie, Wallstein, Göttingen, 2013.

Frühauf, H.: Nachruf auf Karl Willy Wagner, Jahrb. Deutsche Akad. der Wissensch. Berlin, 1954, 397-399, 1956.

Gerwin, R. (Ed.): Max-Planck-Institut für Aeronomie, Berichte und Mitteilungen, Max-Planck-Gesellschaft, München, ISSN 03417778, 4, 1981.

Goubau, G. und Zenneck, J.: Anordnung für Echomessungen an der Ionosphäre, Zs. f. HFT u. Elektroakustik, 46, 77-82, 1932.
Green, A. L.: Early history of the ionosphere, A.W.A. Technical Review, 7, 177-228, 1946.

Halberg, F., Düll-Pfaff, N., Gumarova, L., Zenchenko, T. A., Schwartzkopff, O., Freytag, E. M., Freytag, J., and Cornelissen, G.: 27-day cycles in human mortality: Traute and Bernhard Düll, Hist. Geo Space. Sci., 4, 47-59, doi:10.5194/hgss-4-47-2013, 2013.

Hartmann, G. K.: In Memoriam Walter Dieminger, Deutscher URSI Landesausschuss, Kleinheubach, 2001, (http://www. ursi-landesausschuss.de/dieminger/index.html).

Kenrick, G. W. and Pickard, G. W.: Summary of progress in the study of wave propagation phenomena, P. IRE, 18, 649-668, 1930.

Kertz, W.: Julius Bartels, gest. am 6. März 1964, Nachr. d. Akad. der Wissensch. Göttingen, Jg. 1964, 22, 309-317, Vandenhoek \& Ruprecht, Göttingen, 1965.

Maxwell, J. C.: A Treatise on Electricity and Magnetism, Oxford, 1873.

Mögel, H.: Über die Beziehungen zwischen Empfangsstörungen bei Kurzwellen und den Störungen des magnetischen Feldes der Erde, Telefunken Zeit., 11, 14-31, 1930.

Seiler, M. P.: Kommandosache Sonnengott. Geschichte der deutschen Sonnenforschung im Dritten Reich und unter alliierter Besatzung, H. Deutsch, Frankfurt am Main, 2007.

Scheffczyk, S.: Physiker Karl Försterling - ein Wissenschaftler am Puls der Zeit, in: Harzer Volksstimme, 28 July 2011, 14, 2011.

Schmucker, G.: Jonathan Zenneck 1871-1959, eine technischwissenschaftliche Biographie, Dissertation, Fakultät 8, Historisches Institut, Abteilung für Geschichte der Naturwissenschaften und Technik der Universität Stuttgart, Stuttgart, 1999.

Stoffregen, W.: The Heirich-Hertz-Institut expedition to Tromsö during the International Polar Year 1932-33, Ann. Geophys., 1, 387-390, 1983, http://www.ann-geophys.net/1/387/1983/.

Schwering, F.: In Memoriam Dr. Georg Goubau, IEEE Antennas and Propagation Society Newsletter, February 1981, 8, 1981.

Zenneck, J.: Braun, Karl Ferdinand, in: Neue deutsche Biographie, Bd. 2, Behaim - Bürkel, Duncker \& Humblot, Berlin, 554-555, 1955. 